Revista Eletrônica Geografar, Curitiba, v. 2, Resumos do VI Seminário Interno de Pós-Graduação em Geografia, p. 39-39. Junho/2007

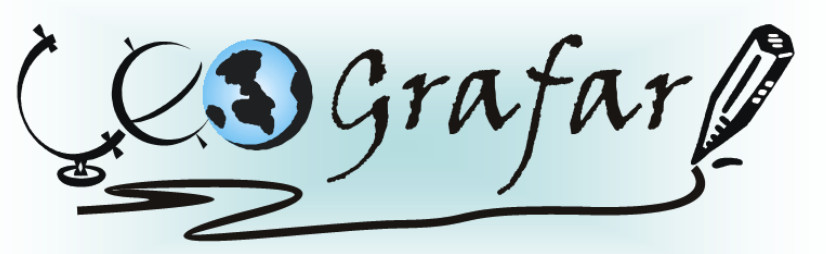

Revista Eletrônica do Programa de Pós-Graduação em Geografia - UFPR

\title{
ORGANIZAÇÃO SÓCIO-POLÍTICA E COESÃO TERRITORIAL: CONSTRUINDO A CAPACIDADE GOVERNATIVA REGIONAL
}

\author{
JULIANO GERALDI ${ }^{1}$
}

O conceito de região é, em seu princípio, referente à autonomia política de uma porção do território frente ao poder central. A construção desta autonomia deve identificar e transcender as múltiplas territorialidades das instituições, atores e outros aspectos concernentes aos processos de construção da capacidade governativa regional - principal responsável pela manutenção de um projeto político. Além disso, faz-se necessário que a região possua coesão territorial suficiente para se por como um ente o mais autônomo possível frente a um processo de desenvolvimento globalizado. Esta coesão é construída a partir de uma base coletiva que represente o território politicamente coeso e, por conseguinte, em consonância com os ideários coletivos regionais. A organização política e social não presume que as relações institucionais sejam sempre cooperativas, elas podem ser, ainda, conflituosas ou neutras. O estudo parte da hipótese que é necessário reconhecer a organização e relações internas regionais para identificar o grau de maturação da capacidade governativa da região em questão. Desta forma, tem como objetivo analisar a regionalização decorrente das articulações sociais e políticas que influenciam diretamente na construção da capacidade governativa regional. Isto se dá por três aspectos: identificando e espacializando a atuação dos atores e instituições que atuam diretamente na promoção do desenvolvimento; analisando a relação entre estes atores e instituições, identificando os espaços onde se dão estas relações assim como a análise da articulação entre estes espaços; e contextualizando as relações multiescalares da região. Mesmo levando-se em conta as limitações de se delimitar com exata precisão a ação regionalizadora dos atores e instituições - visto os aspectos sociais e políticos em questão o estudo propõe, como resultado, a identificação da coesão territorial de uma dada região na construção de sua capacidade governativa.

Palavras-chave: organização política e social; coesão territorial; capacidade governativa regional

${ }^{1}$ Mestrando em Geografia - UFPR - email: juliano_geraldi@yahoo.com.br Orientadora: OLGA LUCIA C. F. FIRKOWSKI 